ELORE (ISSN 1456-3010), vol. 20 - 2/2013.

Julkaisija: Suomen Kansantietouden Tutkijain Seura ry.

[http://www.elore.fi/arkisto/2_13/saarinen.pdf]

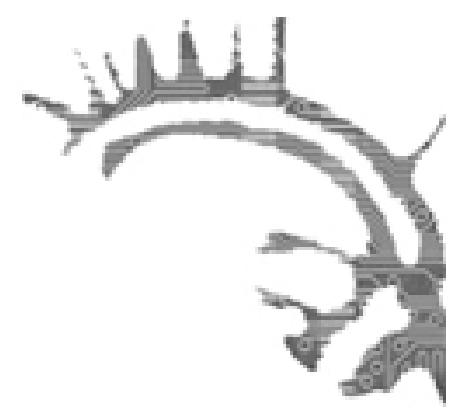

KirJa-ARViO

\title{
LAATOKAN VALAMO JA HISTORIANKIRJOITUS
}

\author{
Tuija Saarinen
}

PARPPEI, KATI 2013: Laatokan Valamo. 1800-luvun luostari matkailijoiden kuvaamana. Kirjokansi 3. Helsinki: SKS. 267 sivua.

Luostarit ovat aina olleet sekä uskonnollisten että maallistuneiden kävijöiden kiinnostuksen kohteina. Valamon asema on erityinen, sillä sitä pidetään ensimmäisenä Karjalaan perustetuista luostareista. Luostarin sijainti kahden uskonnon, ortodoksisuuden ja luterilaisuuden valtapiirin rajamailla on vetänyt puoleensa runsaasti matkailijoita yli kieli- ja kirkkokuntarajojen. Kati Parppein kirjan Laatokan Valamo. 1800-luvun luostari matkailijoiden kuvaamana taustalla on Parppein 2010 ilmestynyt väitöskirja luostarin historiakuvan muotoutumisesta. Väitöskirjassa hän jäljitti tärkeimpiä Valamon varhaishistoriaa koskevia väitteitä aina niiden alkulähteille saakka. Parppei selvitti, miten ja koska luostarin menneisyyttä koskevat käsitykset ja mielikuvat syntyivät ja miten niitä ylläpidettiin. Valamon varhaishistoriaa käsitellään laajalti myös tässä teoksessa. Sen lisäksi Parppei antaa äänen niille matkailijoille, jotka kävivät saarella 1700-luvun lopun ja 1900-luvun alun välillä. 
Tuija Saarinen: Laatokan Valamo ja historiankirjoitus

\section{RAJASEUDUN LUOSTARIN ARVOITUKSELLINEN VARHAISHISTORIA}

Valamon luostarisaaren varhaisimmat asukkaat olivat suomensukuisia, ja saaren nimi, Valamo, on suomensukuista alkuperää. Valamon sijainti kahden valtakunnan rajalla on vaikuttanut sen historiaan ja saarella sijaitseva luostari on autioitunut useita kertoja Ruotsi-Suomen ja Venäjän taistellessa sen hallinnasta. 1500- ja 1600-lukujen vaihteessa ruotsalaiset valtasivat Valamon, ja se tyhjeni munkeista. Veljestö palasi luostariin lyhyen rauhan aikana, mutta 1611 suomalais-ruotsalaiset joukot valtasivat jälleen Valamon ja veljestö pakeni. Saari autioitui sadaksi vuodeksi. 1715 Vologdan alueen luostarin asukkaat siirtyivät Valamoon. 1700-luvulla valta rajaseudulla vaihtui uudelleen, kun Venäjä valtasi Karjalan alueen takaisin Ruotsilta suuressa Pohjan sodassa (Uudenkaupungin rauha 1721). 1800-luvulla Valamo kehittyi yhdeksi läntisen Venäjän merkittävimmistä ja tunnetuimmista luostareista. Suomen itsenäistyttyä luostarista tuli merkittävä pyhiinvaellus- ja turistikohde. Ortodoksit tekivät Valamoon pyhiinvaelluksia. Luterilaiset puolestaan ihmettelivät luostarin eksotiikkaa ja saaren kauneutta. Talvisodan sytyttyä munkit evakuoitiin Suomeen. Valamon luostarin toiminta aloitettiin saarella uudelleen vasta Neuvostoliiton kukistuttua. Suomen puolelle siirtynyt veljestö perusti Uuden Valamon luostarin Heinävedelle. Se saa huomattavan osan tuloistaan matkailusta ja valittiin vuoden 2012 matkakohteeksi. Myös Laatokan Valamo saa jälleen osansa suomalaisesta matkailijavirrasta.

Valamolla on ollut kävijöitä luostarin perustamisesta lähtien. Valamon perustamisajankohdasta ei tosin ole varmuutta, joten siitä on esitetty kilpailevia teorioita. Arviot perustamisajankohdasta vaihtelevat 900-luvulta 1300-luvulle. Siitepölytutkimusten mukaan luostarisaarella on viljelty paikoitellen jo 500- ja 600-luvuilla ja säännöllisestä maanviljelystä on merkkejä 1200-luvulta alkaen. Mutta valitettavasti ei ole tietoa siitä, olivatko varhaiset viljelijät munkkeja. Luostarin tiedetään varmuudella olleen olemassa jo keskiajalla, mutta edes keskiaikaista Valamoa sivuavia tekstejä on säilynyt hyvin vähän. Niissäkin on vain satunnaisia mainintoja luostarista tai sen perustajista. Tämän lisäksi vähäiset tiedonsirpaleet ovat keskenään ristiriitaisia. Tutkijat ovat 1800-luvulta saakka olleet eri mieltä siitä, mitä niukoista lähteistä pitäisi uskoa, kun luostarin varhaishistoriaa pyritään selvittämään.

\section{LUOSTARIN HISTORIAA TULKITSEMASSA}

Valamon historia on ollut monen kirjoittajan kiinnostuksen kohteena eri vuosisatoina. Parppei kysyykin, miten näihin teksteihin tulisi suhtautua tutkittaessa luostarin menneisyyttä. Miten ja mitä Valamosta kerrottiin 1700-luvun lopulta 1900-luvun alkuun ulottuvana ajanjaksona? Miten nuo kerronnat heijastelevat omaa aikaansa ja kertojan taustaa? Parppei korostaa, että kuvat historiasta ovat täynnä poliittista voimaa ja arvolatauksia. Arvolataukset ovat muuttuneet ja muotoutuneet vuosien myötä. Hän kiinnittää huomiota siihen, miten käsitykset luostarin menneisyydestä hahmottuivat ja kehittyvät 1700- ja 1800-lukujen aikana. Juuri nuo vuosisadat - etenkin jälkimmäinen - olivat 
keskeisiä Valamon historiakuvan kannalta. Sen jälkeen on etupäässä toistettu jo aiemmin esitettyjä väitteitä luostarin varhaisvaiheista.

Parppein lähtöajatuksena ja loppupäätelmänä on, että historia on aina jonkun kirjoittamaa, ja että tuolla jollakin on ollut omat, kulloiseenkin aikakauteen sidotut motiivinsa menneisyyden kuvaamiseen. Se, miten historiaa on kerrottu, paljastaa kiinnostavia asioita kertomisajankohdan arvoista, aatteista ja mentaliteeteista. Valamon historia liittyy kansallisaatteiden siivittämään historiankirjoituksen nousuun. Se on innoittanut etsimään vanhoja käsikirjoituksia kirkkojen holveista, luostareista ja kirjastoista. Valamo oli jo vakiinnuttanut asemansa luostarina, ja sille haluttiin räätälöidä kunniakas ja ajan henkeen sopiva historia. Lähdemateriaalin puutteita paikattiin vähitellen. Osittain paikkaus tapahtui rohkeilla tulkinnoilla, osin mielikuvituksen voimalla. Parppei korostaa, että erilaisia ja eri ajalta olevia kertomuksia Valamon luostarista on luettava oman aikansa taustaa vasten. Nykyisin emme hahmota maailmaa samalla tavoin kuin esimerkiksi 500 vuotta aiemmin. Omasta ajasta nousevat tulkinnat pyrkivät aina mukaan. Myös kirjoittamista ja kopioimista säätelivät tietyt mallit ja vallalla ollut retoriikka. Näitä tekijöitä on nykytutkijan yritettävä tiedostaa ja purkaa auki.

On myös tunnettava se konteksti, jossa kirjoituksia luotiin. Esimerkiksi pyhiä henkilöitä kuten Valamon perustajina kunnioitettuja Sergeitä ja Hermania kuvattaessa heidän luonteeseensa ja elämänkulkuunsa sisällytettiin hurskautta korostavia piirteitä ja tapahtumia. Pyhän elämäkertoihin eli hagiografioihin saatettiin lainata pitkiä osia toisista teksteistä, jotta lopputulos olisi kirjoittajan ja luostarin kannalta tarkoituksenmukainen. Tämä oli oman aikakautensa oikeaoppinen tapa, jolla tuotettiin tietoa maallisen yläpuolella olevista asioista. Eri aikana vallalla ollut ymmärrys totuuden olemuksesta oli yksinkertaisesti erilainen kuin nykypäivän käsitykset siitä.

Eri aikoina Valamossa käyneet tutkimusmatkailijat ja tiedemiehet ovat kirjanneet ylös ensimmäisiä luostarin historiaa koskevia käsityksiä ja tarinoita. Näitä käsityksiä toistettiin suullisina kertomuksina ja kopioitiin - usein muokkaantuneena versiona edelleen uusiin teksteihin, joihin kukin istutti omia käsityksiään ja johtopäätöksiään. Ajatukset ja käsitykset Valamon varhaisvaiheista ja myyttisistä perustajista muovautuivat ja elivät kunkin ajan tarpeiden mukaan. Joskus tekstit kertovat enemmän kirjoittajasta ja hänen arvomaailmastaan kuin Valamon todellisista tapahtumista. Se, miten historiaa on kerrottu, paljastaakin Parppein mukaan kiinnostavia asioita kertomisajankohdan arvoista, aatteista ja mentaliteetista.

\section{VALAMON KUVAAJIA}

Teoksessa Laatokan Valamo. 1800-luvun luostari matkailijoiden kuvaamana Parppei on halunnut antaa äänen heille, jotka tekivät 1800-luvulla luostarimatkan ja halusivat kirjoittaa matkastaan muiden luettavaksi tarkoitetun tekstin. Nämä kirjoittajat olivat tunnettuja tiedemiehiä, kirjailijoita, toimittajia tai nimettöminä esiintyneitä, vähemmän kuuluisia matkustajia. Tarkasteltuna ajankohtana nimittäin oli tapana kirjoittaa lehtiin nimettömänä tai nimimerkillä. Yleisesti ottaen voidaan sanoa, että suomalaiset 
kirjoittajat kuvasivat Valamoa osin toisenlaisista lähtökohdista kuin venäläiset, ja suomalaisten motiiveissa oli eroja sen mukaan, oliko kysymys ortodoksikarjalaisesta vai länsisuomalaisesta luterilaisesta kävijästä.

Valamon kuvaajat ovat siis lähtökohdiltaan hyvin erilaisia. Sen vuoksi julkaistut tekstit ovat täynnä poliittista voimaa ja arvolatauksia. Teos Laatokan Valamo poimii esiin eri kuvauksista historian lisäksi myös kirjoitusajankohtaa tai kirjoittajan taustaa kuvaavia yksityiskohtia. Esimerkiksi yleiseurooppalaiset aatteet heijastuivat eri kävijöiden teksteissä ilmeten eri tavoin: esimerkiksi venäläinen kävijä korosti Valamoa vanhana venäläisenä luostarina, suomalainen karjalaisena. Jokainen kirjoittaja toki oli matkalla yksilönä, ja teki sen mukaisia havaintoja.

Venäläinen kirjailija ja journalisti V.I. Nemorovitš-Dantšenko julkaisi 1887 kuvauksen matkastaan otsikolla Valamo: muistoja luostarisaarilta. Kirjoittaja keskittyi kuvaamaan luostarin historiaa ja vaiheita dramaattisin vedoin. Hän korosti luostarin historiallista merkitystä saarta ympäröineiden heimojen kautta: "Sekavan ja pitkän olemassaolonsa aikana Valamo, kuten Solovetsk pohjoisessa, teki Venäjälle suuren palveluksen: suomalaisten ja karjalaisten heimojen keskellä se ei ollut yksistään valona venäläiselle kansalle, vaan sai myös nuo heimot puhumaan venäjää." Lisäksi hän korostaa, että lähiseudulla asuvat karjalaiset ja tsuhnat olivat kurinalaista väkeä. Luostari esiintyy kirjoituksessa slaavilaisuuden valona suomalaisten ja karjalaisten heimojen keskellä ylläpitäen näin aikakautensa näkemystä, jonka mukaan suomalaiset olivat "epähistoriallinen" kansa ja alueen slaavilainen hallinto kaikille eduksi.

Elias Lönnrot oli yksi tunnetuista 1800-luvun alun Valamon kävijöistä. Hän vieraili saarella ensimmäisellä runonkeruumatkallaan 1828 ja raportoi matkapäiväkirjaansa havaintojaan Valamosta. Lönnrot ei korostanut Valamon venäläisyyttä tai vierautta suhteessa suomalaisuuteen kuten monet muut aikakauden suomalaiskirjoittajat. Sen sijaan Lönnrot pani maltilliseen tyyliin merkille outoina pitämiään tapoja. Hän ei tiennyt, mitä tarjotut ruokalajit ovat tai miksi kirkossa kumarretaan. Hän myös kirjoitti ylös munkkien kertomuksen saaren perustamisesta. Sen mukaan perustajamunkit saapuivat saarelle kivipaadella. Kati Parppein mukaan on ilmeistä, että vesistömatkan motiivi on omaksuttu kertomukseen pyhän Anton Rimljanin matkustustavasta. Antonin 1500-luvulla kirjoitetun elämäkerran mukaan hän matkusti Roomasta Novgorodiin kivilaatalla kelluen. Valamon kirkossa tiedetään olleen Anton Rimlanin ikoni. Kertomusmotiivin lainaaminen pyhältä toiselle on ollut jo keskiajalla yleistä. Kivipaadella kelluminen on mainittu myös muiden luostareiden perustajien matkustustavaksi ja kuuluu Karjalan alueelta kerätyissä kansantarinoissa jättiläisten ja noitien matkustuskeinoihin.

Myöhemmin, kun kansallisuustunteet kuumenivat, myös luostarista kirjoitetut havainnot muuttuivat. 1850-luvun nimetön kirjoittaja julkaisi matkakertomuksensa Suomen Julkisia Sanomia -lehdessä. Hän nosti Laatokan merkityksen esiin kansallisromanttisessa hengessä suomalaisista sankareista ja suomalaisen sukukunnan menneisyydestä kysyen: "Missä ovat Suomen sankarit, jotka muinoin Laatokan selkiä valtasivat venheillään ja miekalla ja tulella hävittivät vihollistensa rantoja?", ja tunsi melankolista kaihoa suurta menneisyyttämme kohtaan. Itse luostari näyttäytyi oudon elämänmuodon ilmentymänä, ja sen hiljaisuus oli "syvä ja kammottava". 
Tuija Saarinen: Laatokan Valamo ja historiankirjoitus

\section{LOPUKSI}

Teos on visuaalisesti antoisa ja toimii sen vuoksi mainiona lahjakirjana Valamon ystäville. Teoksen useammalle aukeamalle on nimittäin sijoitettu ainakin yksi suuri valokuva, piirros, maalaus tai kartta. Kuvitus on peräisin Suomessa sijaitsevista arkistoista ja museoista. Olisi ollut mielenkiintoista nähdä kuvia myös 1800-luvun venäläisistä Valamon kävijöistä ja verrata venäläisten hallussa olevaa kuvamateriaalia suomalaisiin. Sitä, onko kuvia etsitty venäläisistä arkistoista, teos ei mainitse.

Teos on ilmestynyt Suomalaisen Kirjallisuuden Seuran yleistä tietokirjallisuutta julkaisevassa Kirjokansi-sarjassa. Ilmeisesti sen vuoksi teoksessa ei ole taustalla olevan väitöskirjatutkimuksen ja tämänkin teoksen muodostumiseen vaikuttaneen metodologian syvällistä esittelyä. Parppein johdannossa esittämään käsitykseen siitä, että historia on aina jonkun kirjoittama, on helppo kirjan luettuaan yhtyä. Valamon historialla on ollut monta kirjoittajaa. Jokainen heistä on ollut osaltaan luomassa sitä Valamo-suhdetta ja -käsitystä, joka suomalaisilla luostariin tänäkin päivänä on siitä huolimatta, että saariluostari sijaitsee nyt Venäjän valtion alueella. Laatokan saaren Valamo on kasvanut Neuvostoliiton romahdettua yhdeksi suomalaisia eniten kiinnostavista kohteista rajan takaisessa Karjalassa. Valamon saari on yksi menetetyn Karjalan symboleja siinä kuin Viipurin linna tai Säkkijärven polkka. Myös tämän päivän aatteemme vaikuttavat tulevaisuuden historiankirjoitukseen.

Filosofian tohtori Tuija Saarinen toimii tutkijana Suomen Akatemian tutkimusprojektissa Rajaseudun kirjoituskulttuuri ja traditiot Karjalan tutkimuslaitoksella Itä-Suomen yliopistossa. 